\title{
СИБИРСКОЕ КАЗАЧЬЕ ВОЙСКО В ПОСЛЕДНЕЙ ТРЕТИ XIX - НАЧАЛЕ ХХ ВЕКА ПО СПРАВОЧНО-СТАТИСТИЧЕСКИМ ОПИСАНИЯМ Ф.Н. УСОВА: ИСТОЧНИКОВЕДЧЕСКИЙ ОБЗОР
}

\section{SIBERIAN COSSACK ARMY IN THE LAST THIRD OF THE XIX - EARLY XX CENTURY ACCORDING TO THE REFERENCE AND STATISTICAL DESCRIPTIONS OF F.N. USOV: A SOURCE STUDY REVIEW V. Skopa}

Summary: The article analyzes the historical, ethnographic and statistical descriptions of F. N. Usov concerning the Siberian Cossack army. This source allows you to isolate information in relation to such objects as: building a house and its improvement; courtyards and outbuildings; livestock; clothes; food; hot drinks; food supplies; agricultural tools; methods of cultivating the land and harvesting bread and hay. Forming information about the life and occupations of the Siberian Cossacks, special attention was paid to clothing, food and provisions. The characterization of food allows us to focus on the ethnography of the Cossack cuisine, and at the same time, to supplement the understanding of everyday customs, customs and characteristics of the Cossack population.

Keywords: Siberian Cossacks, statistical information, source, F.N. Usov, reference descriptions.

\author{
Скопа Виталий Александрович \\ Д.и.н., Алтайский государственный педагогический \\ университет (2. Барнаул) \\ sverhtitan@rambler.ru
}

Аннотация: В статье анализируются историко-этнографические и статистические описания Ф.Н. Усова, касающиеся Сибирского казачьего войска. Данный источник позволяет вычленить сведения, в отношении таких объектов как: постройка дома и его благоустройство; дворы и надворные постройки; домашний скот; одежда; пища; горячие напитки; съестные припасы; земледельческие орудия; способы обработки земли и уборки хлеба и сена. Формируя сведения о жизни и занятиях сибирских казаков отдельное внимание было уделено одежде, пище и съестным припасам. Характеристика пищи позволяет сделать акцент в отношении этнографии казачьей кухни, а вместе с тем, дополнить понимание о житейских нравах, обычаях и особенностях казачьего населения.

Ключевые слова: сибирские казаки, статистические сведения, источник, Ф.Н. Усов, справочные описания.
$\mathrm{C}$ ибирские казаки по своему происхождению являлись казаками служивыми. Они, как отмечал Г.Е. Катанаев, набирались «по царскому указу, воеводскому приказу» [1, с. 8], что во многом и обусловило их специфику. В отличие от донских, сибирские казаки располагались не компактным районом проживания, а заселили сравнительно узкую пограничную полосу протяженностью свыше 2000 верст, что во много предопределило их быт, занятия и специфику деятельности.

Существенный вклад в изучение Сибирского казачества внес Ф.Н. Усов [2]. По происхождению он был сибирским казаком. По окончании курса в Омском кадетском корпусе, он служил в штабе Сибирского генерал-губернатора офицером для особых поручений и неоднократно бывал в военных походах в степи. Значительную часть своей служебной деятельности Усов посвятил Сибирскому казачьему войску. Генерал-губернаторы Казнаков, Мещеринов и Колпаковский часто возлагали на него поручения, касающиеся хозяйственной и экономической деятельности Сибирского казачьего войска [3].

Статистическое описание Сибирского казачьего во- йска Ф.Н. Усова как исторический источник позволяет вычленить историко-этнографические сведения, касающиеся таких направлений как:

- постройка дома и его благоустройство;

- дворы и надворные постройки;

- описание домашнего скота;

- одежда;

- пища;

- горячие напитки;

- съестные припасы;

- земледельческие орудия;

- способы обработки земли и уборки хлеба и сена $[4,5,6]$.

Формируя сведения о постройке домов в казачьей среде, Ф. Н. Усов черпал сведения через непосредственное наблюдение, а также контакты с самими казаками. Весьма содержательным и интересным является описание по данной части, где автор делает акцент на представление жилища, констатируя, что «у казаков строения деревянные, а предпочтение отдавалось сосне» [4]. Формируя сведения, Ф.Н. Усов отметил, что в некоторых поселках по Иртышу много домов вырублено из мелкого 
березового леса, который «промерзал зимой, был сырым и крайне вредным для здоровья» [4]. В горных станицах Бийской линии строительным материалом преимущественно выступала растущая в горах пихта, а также лиственница, из которой «возникла станция Алтайская» [4]. Эти описания отчетливо формируют картину, касающуюся строительного материала, из которого казачье население рубило дома. Отдельное внимание при описании было обращено на архитектуру строения. Так, Ф.Н. Усов отмечал, что казачьи дома и иные жилые постройки «средней руки» по своему стилю и виду не имели особого архитектурного ландшафта. От простого крестьянского дома, казачий отличался пропорциональностью частей. Так, в нем крыша «не резала глаза своею высотой, окошки были очень малых размеров. Улицы были разбиты шире и более благоустроены» [4]. Описывая казачьи строения, Ф.Н. Усов параллельно делал зарисовки, которые сопровождались небольшими описаниями, где было свойственно сравнение с иными строениями. Казачий дом в описаниях представлял собой невысокое, одноэтажное, бревенчатое строение, в котором было два, а иногда четыре окна, выходящих на улицу. Крыша была либо в два ската, либо в четыре. Дом всегда был разделен «холодными сенями на две половины» [4]. Характеризуя строение, Ф.Н. Усов отмечает внутреннее убранство, поясняя, что потолки и стены белятся глиной, полы каждую субботу моют, скоблят и покрывают половиками. В зимний период вставляют в одной «чистой комнате двойные рамы» [4]. Очень подробно Ф.Н. Усов описывает внутренне устройство дома и расположение утвари «в углу, против входа, образа. Очень часто занимает весь угол большая икона суздальской живописи. Зажиточные имеют перед образом лампадку с деревянным маслом, а на угловом столике псалтырь в кожаном переплете» [4]. Данные сведения позволяют увидеть социальную дифференциацию казачьей среды, особенности внутреннего расположения в отношении входа в дом.

Отдельное внимание Ф.Н. Усов уделил надворным постройкам, как неотъемлемой части хозяйственного быта казаков. «Двор окружен забором из тонкого круглого леса, еще чаще плетнем; ворота на верее, решетчатые из узеньких пластин и полуобтесанных жердей. Кроме переднего двора, заключающего разные надворные постройки, есть еще задний, отгороженный от первого также забором с воротами, назначаемый для скота. Зимою этот задний двор, для большей теплоты, закрывается сверху жердями, хворостом, соломой и сеном. В переднем дворе помещаются один или два амбара, сарай или навес для телег, саней, колес, сбруи. Все эти постройки бревенчатые, с крышами из теса, а больше дерновыми и берестяными» [4]. Данные сведения позволяют отследить уровень хозяйственного развития, многообразие строений определяет широкую хозяйственную сферу казаков, их непосредственную причастность к земле. В продолжении описания хозяйственного быта внима- ние уделено домашнему скоту. «Станичными жителями содержатся лошади, рогатый скот, овцы, а в некоторых местах в небольшом количестве козы и свиньи. Из домашней птицы имеют кур, уток, гусей и индеек» [4]. Формируя материал, Ф.Н. Усов показал социальную дифференциацию казачьего сообщества. «Степень зажиточности казачьей семьи выражается в количестве скота. Семья среднего состояния имеет от 3 до 10 лошадей, от 2 до 4 дойных коров с десятком подростков (бычков и телят) и от 10 до 30 овец и коз. Зажиточная семья держит от 15 до 50 лошадей и больше, дойных коров от 6 до 10, гулевого рогатого скота и подростков от 50 до 100 голов и около сотни овец» [4]. Сопоставляя разные места расселения Сибирских казаков, Усов отмечал, что в Павлодарском и Семипалатинском уездах, хозяева постоялых дворов разводят до 100 штук птицы. «У семьи же бедного состояния, если есть скот, то не более одной лошади, одной коровы с двумя подростками и от 3 до 5 овец» [4]. Характеризуя подворье в казачьих селениях Ф.Н. Усовым привлекались статистические сведения, которые содержались в войсковом казачьем правлении и частично представлялись в общем статистическом отчете по казачьему войску за каждый год.

Формируя сведения и жизни и занятиях сибирских казаков отдельное внимание Ф.Н. Усовым было уделено одежде, пище и, весьма интересно, съестным припасам. Так, характеризуя одежду он отмечал, что в одежде казаков много восточного, перенятого от киргиз и татар, констатируя, что это происходит от «дешевизны бумажных среднеазиатских материй и разных предметов киргизской одежды, сравнительно с привозимыми в станицы русскими изделиями» [4]. Важно отметить, что различие в одежде так же дифференцировало казачье население. Так, на Бийской линии, где жители преимущественно земледельцы, а также в Петропавловском и Кокчетавском уездах, где было много казаков, из переселившихся крестьян, холст для белья, сукно и армянина на зипуны у них были самошитные, а в одежде был заметен крестьянский оттенок $[4,8]$.

Характеристика пищи позволяет сделать акцент в отношении этнографии казачьей кухни, а вместе с тем, дополнить понимание о житейских нравах, обычаях и особенностях казачьего населения. Так по заметкам Ф.Н. Усова в средне зажиточных семьях утром и вечером пили чай с пшеничными калачами; сахар употребляли только по праздникам. В выходные и праздничные дни готовили популярные во всей Сибири горячие шаньги. В пост было обыкновенное кушанье - «щи, без приправы, из серой капусты или с ячневой крупой, горох, рыба. В скоромные дни - щи и картофельная похлебка с приправами, каша на молоке просяная и ячневая. В праздничные дни - студень, щи с говядиной или бараниной, жаркое из кур, гусей, уток» [4]. Чаще всего на ужин шло то, что оставалось от обеда. 
Интересным и познавательным является материал, касающийся употребления горячительных напитков казаков. Так, по описанию Ф.Н. Усова отмечается, что водка и вино употреблялись станичными жителями очень часто и в значительных размерах. Качалось это и каждого семейного праздника, и свадьбы, и именин. «На общественных сходах даже обратилось в обычай - требовать по ведру и по два ведра водки с каждого избираемого на общественную должность лица» [4].

Внимание Ф.Н. Усова было обращено и на заготовку продуктов в прок. Эти сведения собирались посредством бесед с обывателями казачьей общины и личного наблюдения. Усов констатировал, казаки заготовками занимаются впрок - сушат и вялят. «Солят мясо и рыбу для употребления летом; огурцы, капусту, арбузы на зиму. Мясо и рыбу заготовляют на лето также в сушеном и вяленом виде» [4]. В данном заготовительном процессе так же была видна социальная дифференциация казачьего населения. Зажиточная семья готовила впрок от 10 до 25 пудов мяса соленого и вяленого, а среднего достатка от 4 до 8 пудов. В целом хозяйственные дела казачьего населения были очень разнообразные как объему выполняемых работ, так и количеству мероприятий. В тоже время быт, в большинстве своем, был однообразным.

К тому же казачье население активно занималось и земледелием. В описаниях Ф.Н. Усова содержательным является сюжет, касающийся характеристики земледельческих орудий и способов обработки земли и уборки хлеба и сена. Самым распространенным орудием для вспашки земли была обыкновенная двухколесная соха, с одним железным сошником. В нее впрягали от двух до четырех лошадей, смотря по твердости грунта. В некоторых местностях войска - в Кокчетавском уезде, в поселениях Вознесенской станицы Петропавловского уезда и местами на Иртышской линии (по Павлодарскому и Усть-Каменогорскому уездам) - больше употребляли малороссийский плуг (сабан), куда запрягали от 6 до 8 лошадей или быков [4].

При существовавшей во всем войске переложной системе хлебопашества удобные земли не распределялись на участки между общественниками. Каждый вспахивал где хотел и сколько мог. Для удобства работ пашни разбивались на продолговатые полосы, которые назывались загонами.

Чаще всего подготовка поля под посев ограничивалась двумя вспашками, что называлось «двоением пашни». Целину, или залог в первый раз распахивали в июне и оставляли выветриваться до следующей весны, а после распахивали во второй раз и засеивали пшеницей. Земли, на которых уже сеяли, переводили под яровые хлеба, распахивали осенью, а затем весною перед посевом перепахивали. Иногда обработка земли упрощалась. Так, для посева льна и конопли вспахивали новь всего один раз, весною, и через несколько недель засеивали. После ржи на ржаное поле овес сеяли без вспахивания, а только после высева боронили. Для сенокошения, луговые местности в каждом станичном обществе делились на паи каждого. Трава косилась один раз в год. Скошенное сено просушивали, а затем сгребали в копны. Для сенокошения нередко нанимали рабочих или «делали помочи» [5].

Таким образом, историко-этнографические описания Ф.Н. Усова позволяют увидеть целостную картину жизни, быта и занятий казачьего населения в Сибири. Репрезентативный нарративный источник существенно обогащает знания по вопросу казачьего населения в территориальных границах столь обширного региона. Формируя сведения посредством личного наблюдения, непосредственного контакта с местными казаками и использования официальных данных из статистических отчетов Ф.Н. Усову удалось комплексно, с эмоциональным оттенком, показать казачью среду с их нравами и обычаями.

\section{ЛИТЕРАТУРА}

1. Катанаев Г.Е. Западносибирское служилое казачество и его роль в обследовании и занятии русскими Сибири и Средней Азии. Вып. 1. СПб., 1908.

2. Адам А.Я. Сибирское казачье войско: новые аспекты управления во второй половине XIX в.: сборник научных трудов. Азиатская Россия: люди и структуры империи. Омск, 2016. 325-329.

3. Ивонин А.Р., Колупаев Д. В. История Алтайского казачества. Алтайские казаки в XVIII-XIXвв. Барнаул, 2008.

4. Усов Ф.Н. Статистическое описание Сибирского казачьего войска. СПб., 1879.

5. Усов Ф.Н. Справочная книжка о Сибирском казачьем войске. Тюмень, 1873.

6. Усов Ф.Н. Очерки по истории Сибирского казачьего войска // «Акмолинские губернские ведомости» за 1882 и 1883 гг.

7. Ерошкин Н.П. История государственных учреждений дореволюционной России. М., 2008.

8. Недбай Ю.Г. История казачества Западной Сибири, 1582-1808 гг. Ч. 1-4, 0мск, 1996.

(с) Скопа Виталий Александрович (sverhtitan@rambler.ru). 